\title{
LA-ICP-MS-MS coupled with reactive gases: new improvement for in situ analyses of halogens elements and other volatile trace elements.
}

\author{
BENOIT CARON 1 , BENOIT VILLEMANT2, BENOIT \\ DUBACQ 3 AND SARAH FIGOWY4
}

1Sorbonne Université, UMR ISTeP 7193, ALIPP6 4 place

Jussieu 75005 Paris France and benoit.caron@sorbonneuniversite.fr

2benoit.villemant@sorbonne-universite.fr

3benoit.dubacq@sorbonne-universite.fr

4 sarah.figowy@sorbonne-universite.fr

The recent developments of ICP-MS-MS (Agilent 8900) technique coupled with a laser ablation (Photon Machine Excimer $193 \mathrm{~nm}$ ) allows in situ analyses of halogens and many other volatile elements in geological material.

Chlorine $(\mathrm{Cl})$, bromine $(\mathrm{Br})$ and iodine $(\mathrm{I})$ are directly measured in minerals or glasses (residual glass or melt inclusions) of natural systems, with beam sizes as low as 20 $\mu \mathrm{m}$. The LA-ICP-MS/MS technique has many advantages compared to classical LA-ICP-MS for analyzing trace elements in geological material and that have numerous isobaric interferences.

Plasma produced by laser ablation strongly reduces the isobaric interferences due to the production of oxides and double charged ions, (2) The MS/MS mode with no gas in the reaction cell, compared to single quadrupole mode (MS), strongly improves the mass resolution, reduces the polyatoms interferences and increases peak/background ratios of many elements due to the double $\mathrm{M} / \mathrm{Z}$ selection, (3) The use of collision or reaction gases $\left(\right.$ e.g. $\left.\mathrm{He}, \mathrm{H}, \mathrm{N}_{2} \mathrm{O}\right)$ in the reaction cell bracketed by the two quadrupoles, allows very selective suppression of interfering species through selective reactions (as the production of $\mathrm{ClH}_{+}$and $\mathrm{ClH}_{2}+$ using $\mathrm{H}_{2}$ ). In addition reaction or collision gas in cell, focuses the ion flow and improves the signal intensity.

It is shown that this technique allows in situ analyses of $\mathrm{Cl}, \mathrm{Br}$ in almost the whole composition range of geological material at a good precision. Analytical improvements for low I contents $(<100 \mathrm{pb})$ are necessary. Many other trace elements as $\mathrm{Li}, \mathrm{Be}$ and $\mathrm{B}$ can also be measured with this technique simultaneously with halogens (applied on BHVO-2G, BIR$1 \mathrm{G}$ and BCR-2G, ATHO and RGM).

LA-ICP-MS/MS using both no gas and gas reaction modes may become the reference method for in-situ analysis of $\mathrm{Cl}, \mathrm{Br}$ and $\mathrm{I}$ and many other volatile elements in magmatic rocks and most geological material. 
This abstract is too long to be accepted for publication.

Please revise it so that it fits into the column on one page. 